\title{
KONSTATIRING HAKIM DALAM PERKARA PERCERAIAN YANG DIPUTUS VERSTEK DI PENGADILAN NEGERI JAKARTA UTARA
}

\author{
Elfirda Ade Putri \\ Fakultas Hukum, Universitas Bhayangkara Jakarta Raya \\ Email: elfirdade.putri@gmail.com
}

Diterima : 27 Sep 2020 | Direvisi : 29 Okt 2020 | Disetujui : 15 Nov 2020 | Diterbitkan : 14 Des 2020

\begin{abstract}
This research is related to the judge's constituency in the Divorce Case decided by Verstek at the North Jakarta District Court. This study aims to determine the application of the law of implementing verstek procedure in the absence of the defendant in a divorce case. As for the problems in this writing are: (1) Is the defendant's absence in the decision of verstek in Decision Number 62 / Pdt.G / 2017 / PN Jkt. UTR is in accordance with applicable law; (2) What is the judge's consideration in deciding on divorce due to continuous disputes. The legal research method used is normative juridical legal research using a deductive approach in analyzing data. The results obtained through this research are: (1) Implementation of verstek decisions in divorce cases is carried out in accordance with the flow of the case which is a provision in civil procedural law, so that the verstek decision in the decision is in accordance with the applicable legal provisions; (2) The basis for the considerations described by the panel of judges in their decision is in accordance with the applicable civil procedural law. The defendant's absence is deemed to have accepted the plaintiff's lawsuit and the verdict is in accordance with Article 125HIR / Article 149RBg.
\end{abstract}

Keywords: Legal Protection, Divorce, Continuous Disputes

\begin{abstract}
ABSTRAK
Penelitian ini berkaitan dengan konstatiring Hakim dalam Perkara Perceraian yang diputus Verstek di Pengadilan Negeri Jakarta Utara. Penelitian ini bertujuan untuk mengetahui penerapan hukum pelaksanaan acara verstek pada ketidakhadiran tergugat dalam perkara perceraian. Adapun yang menjadi permasalahan dalam penulisan ini adalah: (1) Apakah ketidakhadiran tergugat pada penjatuhan putusan verstek dalam Putusan Nomor 62/ Pdt.G/2017/PN Jkt. Utr telah sesuai dengan hukum yang berlaku; (2) Bagaimanakah pertimbangan hakim dalam memutus cerai akibat perselisihan terus menerus. Metode penelitian hukum yang digunakan adalah penelitian hukum yuridis normatif dengan menggunakan pendekatakan deduktif dalam menganalisis data. Adapun hasil yang diperoleh melalui penelitian ini adalah: (1) Pelaksanaan putusan verstek dalam perkara perceraian dilaksanakan sesuai dengan alur perkara yang merupakan ketentuan dalam hukum acara perdata, sehingga putusan verstek dalam putusan tersebut sudah sesuai dengan ketentuan hukum yang berlaku; (2) Dasar pertimbangan yang uraikan majelis hakim dalam putusannya telah sesuai dengan hukum acara perdata yang berlaku. Ketidakhadiran tergugat dianggap telah menerima gugatan penggugat dan penjatuhan putusan telah sesuai dengan Pasal 125HIR/Pasal 149RBg.
\end{abstract}

Kata Kunci: Perlindungan Hukum, Perceraian, Perselisihan Terus Menerus 


\section{PENDAHULUAN}

Perkawinan bila dilihat dari Pasal 1 Undang-Undang Nomor 1 Tahun 1974 tentang Perkawinan diartikan sebagai ikatan lahir batin antara seorang pria dengan seorang wanita sebagai suami isterti yang bertujuan membentuk keluarga atau rumah tangga yang bahagia dan kekal berdasarkan Ketuhanan Yang Maha Esa. Definisi perkawinan di sini menutup kekurangan definisi perkawinan pada Pasal 26 Kitab Undang-Undang Hukum Perdata (KUHPerdata) yang dahulu, di mana perkawinan diartikan sebagai pertalian yang sah antara seorang laki-laki dan seorang perempuan untuk waktu yang lama. Definisi seperti ini hanya melihat perkawinan dari hubungan keperdataan saja dengan melihat pada segi-segi formalitasnya dan sifat yuridisnya. ${ }^{1}$

Dari perumusan Pasal 26 KUHPerdata dapat dilihat bahwa tidak diperhatikannya beberapa hal seperti tidak dicantumkannya upacara-upacara perkawinan, tidak dilihatnya larangan-larangan untuk kawin seperti yang ditentukan peraturan agama, tidak dimungkinkannya cerai, tidak diperhatikannya faktor-faktor biologis maupun motif yang mendorong para pihak untuk melangsungkan perkawinan. Walaupun demikian terdapat beberapa hal positif dalam pasal ini seperti perkawinan monogami, ${ }^{2}$ hakikat perkawinan adalah lembaga yang abadi yang hanya bisa putus dengan kematian, dan cerai hanya diperbolehkan untuk alasan-alasan tertentu, sifatnya limitatif. Membentuk keluarga yang bahagia rapat hubungannya dengan keturunan yang pula merupakan tujuan perkawinan khususnya dari segi agama untuk menciptakan generasi manusia baru yang meneruskan eksistensi manusia di bumi. ${ }^{5}$ Pemeliharaan dan pendidikan bagi mereka ini menjadi hak dan kewajiban orang tua.

Dalam perkawinan, semua orang tentunya menghendaki kehidupan rumah tangga yang bahagia, kekal dan sejahtera, namun tidak semua orang dapat mencapai kehidupan perkawinan yang dicita-citakan tersebut. Hal ini dikarenakan terdapatnya banyak hal yang mendorong terjadi perceraian. Secara mendasar, perceraian adalah salah satu hal yang mengakibatkan hapusnya perkawinan. Suatu perkawinan dapat hapus oleh beberapa hal antara lain jika salah satu pihak meninggal, jika salah satu pihak menikah lagi setelah mendapatkan izin hakim, atau jika salah satu pihak meninggalkan tempat tinggalnya hingga sepuluh tahun lamanya. Akhirnya perkawinan dapat dihapuskan dengan perceraian. ${ }^{6}$ Menurut Pasal 38 Undang-Undang Nomor 1 Tahun 1974 tentang Perkawinan, perkawinan dapat putus karena kematian, perceraian maupun putusan pengadilan. Sebelum disahkannya Undang-Undang Nomor 1 Tahun 1974 tentang Perkawinan, KUHPerdata mengatur bahwa alasan-alasan yang dianggap cukup dan sah bagi suami/istri untuk mengajukan perceraian antara lain:

(1) Salah satu pihak melakukan zina (overspel);

(2) Ditinggalkan dengan sengaja (kwaadwillige verlating);

(3) Penghukuman yang melebihi 5 tahun karena dipersalahkan melakukan suatu kejahatan; dan

(4) Penganiayaan berat yang membahayakan jiwa (Pasal 209 KUHPerdata)

Undang-Undang Nomor 1 Tahun 1974 tentang Perkawinan mengatur pengajuan perceraian dalam Pasal 39 yang isinya antara lain:

a) Perceraian hanya dapat dilakukan di depan sidang pengadilan setelah pengadilan yang bersangkutan berusaha dan tidak berhasil mendamaikan kedua belah pihak; 
b) Untuk melakukan perceraian harus ada cukup alasan, bahwa antara suami istri tersebut tidak akan dapat hidup rukun sebagai suami istri;

c) Tata cara perceraian di depan sidang pengadilan diatur dalam peraturan perundang-undangan tersendiri.

Butir 2 Pasal 39 Undang-Undang Nomor 1 Tahun 1974 tentang Perkawinan mengenai cukupnya alasan untuk melakukan perceraian dengan artian bahwa antara suami dan istri tidak akan dapat hidup rukun kembali dalam kehidupan rumah tangga, kemudian dijabarkan lebih lengkap dalam Pasal 19 Peraturan Pemerintah Nomor 9 Tahun $1975 .{ }^{8}$ Pasal tersebut mengatur bahwa hal-hal yang dapat dijadikan alasan untuk mengajukan perceraian antara lain:

1) Salah satu pihak berbuat zina atau menjadi pemabuk, pemadat dan lain sebagainya yang sukar disembuhkan;

2) Salah satu pihak meninggalkan pihak lain selama 2 (dua) tahun berturut-turut tanpa alasan yang sah atau karena hal lain di luar kemampuannya;

a) Salah satu pihak mendapat hukuman penjara 5 (lima) tahun atau hukuman yang lebih berat setelah perkawinan berlangsung;

b) Salah satu pihak melakukan kekejaman atau penganiayaan yang membahayakan pihak lain;

c) Salah satu pihak mendapat cacat badan/penyakit dengan akibat tidak dapat menjalankan kewajiban sebagai suami/istri; and

d) Antara suami/istri terus menerus terjadi perselisihan dan pertengkaran serta tidak ada harapan akan hidup rukun lagi dalam rumah tangga.

Di samping alasan tersebut di atas, terdapat faktor lain yang berpengaruh dalam terjadi perceraian, yaitu: faktor ekonomi atau keuangan, faktor hubungan seksual, faktor agama, faktor pendidikan, faktor usia muda dan lain sebagainya. Salah satu cara yang dapat ditempuh adalah gugatan lewat pengadilan, di mana hakim akan bertindak sebagai perantara bagi pihak-pihak yang bersengketa, sehingga hak dan kewajiban dari warga negara akan senantiasa terjamin. ${ }^{9}$ Dalam hal penyelesaian perkara lewat pengadilan, maka prosedurnya harus sesuai dengan ketentuan hukum acara perdata. Adanya pengajuan perkara ke Pengadilan yang dilakukan oleh suami maupun istri telah menandai bahwa perceraian itu tanpa membedakan jenis kelamin dan hak hukum warga negara dapat dijatuhkan oleh masing-masing pihak.

Oleh karena itu, keduanya juga harus memudahkan proses jalannya perkara dengan mematuhi aturan hukum dan hadir di persidangan, sehingga pencapaian keadilan dapat terpenuhi dan perkara dapat diselesaikan berdasarkan aturan hukum. Selain kehadiran kedua belah pihak yang berperkara, hal lain yang sangat berperan penting dalam persidangan adalah posisi hakim sebagai pihak yang akan memutuskan perkara juga sebagai pihak yang akan mendamaikan kedua belah pihak. Posisi hakim dalam persidangan sangatlah penting, hakim diharuskan mendengarkan kedua belah pihak (Pasal $121 \mathrm{HIR} /$ Pasal $124 \mathrm{RBg}$ ), ketika kedua belah pihak yang dipanggil di muka sidang mendapat perlakuan yang sama sehingga keputusan yang dihasilkan berdasarkan hukum yang tepat.

Hukum acara perdata terdapat asas audi et alteram partem yang pada pokoknya berarti bahwa kedua belah pihak harus didengar. Kedua belah pihak yang berperkara harus sama-sama diperhatikan, berhak atas perlakuan yang sama dan adil serta masingmasing harus diberi kesempatan untuk menyampaikan pendapatnya. Hal ini berarti bahwa hakim tidak boleh menerima keterangan dari salah satu pihak sebagai dasar, 
bila pihak lawan tidak didengar atau diberi kesempatan untuk mengeluarkan pendapatnya. Jadi dalam pemeriksaan perkara di muka persidangan harus berlangsung dengan hadirnya kedua belah pihak, jika hanya salah satu pihak saja yang hadir maka pemeriksaan perkara tidak boleh dimulai dan sidang harus ditunda.

Jika berpegang dan asas tersebut harus diikuti dengan kaku maka akan terjadi kekacaian dan permasalahan, karena sering terjadi dalam praktek pengadilan kedua pihak yang berperkara telah dipanggil secara patut untuk hadir dalam persidangan pada hari sidang yang telah ditentukan oleh hakim, tetapi ternyata di antara kedua belah pihak yang berperkara tersebut hanya salah satu pihak yang hadir. Sehubungan dengan hal di atas, Hukum Acara Perdata memberi jalan keluar dengan memberikan peraturan tentang gugur (Pasal $124 \mathrm{HIR}$ ) dan verstek (Pasal $125 \mathrm{HIR}$ ). Apabila pada hari sidang yang telah ditentukan untuk hadir penggugat tidak hadir dan tidak mengirim wakil atau kuasanya meskipun ia telah dipanggil dengan patut, maka gugatan dianggap gugur dan penggugat berhak mengajukan kembali gugatannya setelah ia membayar lebih dulu biaya perkaranya.

Masalah lain verstek dalam perkara perceraian adalah permasalahan pembuktian, di mana Hukum Acara itu dibagi dalam Hukum Acara Materiil dan Hukum Acara Formil. Peraturan mengenai alat-alat pembuktian, termasuk dalam bagian yang pertama yang dapat juga dimasukkan ke dalam Kitab Undang-Undang Hukum Perdata Materiil. ${ }^{10}$ Berdasarkan Undang-Undang Republik Indonesia Nomor 3 Tahun 2006 tentang Peradilan Agama, Hukum Acara yang berlaku pada Pengadilan Agama adalah Hukum Acara yang berlaku pada Pengadilan dalam lingkungan Pengadilan Umum, kecuali yang diatur secara khusus dalam undang-undang ini. Sehingga bila ditinjau dari peraturan perundang-undangan ini, maka jelaslah tidak terdapat ketentuan khusus bagi pembuktian putusan verstek perkara perceraian terjadi dalam perkara perceraian dengan Putusan Nomor 62/Pdt.G/2017/PN. Jkt. Utr, di mana hakim menjatuhkan putusan verstek dikarenakan tergugat dalam perkara perceraian tersebut tidak hadir dan juga tidak mengirimkan wakil atau kuasa hukumnya

Berdasarkan hal-hal tersebut, dapat dirumuskan beberapa masalah sebagai berikut; Apakah ketidakhadiran tergugat pada penjatuhan putusan verstek dalam Putusan Nomor 62/Pdt.G/2017/PN. Jkt. Utr telah sesuai dengan hukum yang berlaku? Dan bagaimanakah pertimbangan hakim dalam memutus cerai melalui putusan verstek dalam Putusan Perkara Nomor 62/Pdt.G/2017/PN Jkt. Utr?

\section{PEMBAHASAN}

\section{Pengertian Perkawinan dan Asas Dalam Perkawinan}

Perkawinan merupakan hubungan hukum antara suami dan istri yang menimbulkan akibat hukum, akibat hukumnya yaitu timbulnya hak dan kewajiban; misalnya kewajiban untuk bertempat tinggal yang sama, mendidik anak-anak dan memberikan nafkah. Berbicara mengenai hubungan antara suami dan istri sebagai akibat dilangsungkannya perkawinan, Wirjono Prodjodikoro berpendapat bahwa kalau seorang perempuan dan seorang laki-laki berkata sepakat untuk melakukan perkawinan satu sama lain, ini berarti mereka saling berjanji akan taat kepada perkawinan satu sama lain, ini berarti mereka saling berjanji akan taat kepada peraturan-peraturan hukum yang berlaku mengenai hak dan kewajiban masingmasing pihak selama dan sesudah hidup bersama itu berlangsung. ${ }^{1}$ 


\section{Hak dan Kewajiban Suami - Istri}

Perkawinan merupakan suatu ikatan lahir batin antara seorang pria dan seorang wanita sebagai suami istri dengan tujuan membentuk keluarga bahagia. Dasar perkawinan adalah saling mencintai satu sama lain, saling menerima apa adanya. Karena mereka adalah insan-insan dari pola hidup yang berlainan. Suami dan istri masing-masing datang dari dua tipe karakter, sifat, tabiat, perilaku, kebiasaan dan juga dari dua keluarga yang berbeda. Oleh karena mereka saling mencintai dan saling ketertarikan satu sama lain, maka terjadilah perkawinan. Kehidupan kedua insan yang berbeda ini hakikatnya adalah saling berkorban demi tegak dan utuhnya keharmonisan rumah tangga.

Perkawinan juga adalah hubungan hukum antara suami dan istri. Hubungan hukum itu menimbulkan akibat hukum berupa hak dan kewajiban. Setelah mereka kawin dan sebagai suami istri, mereka mempunyai beban yang diletakan oleh undang-undang yaitu memikul kewajiban yang luhur. Suami dan istri mempunyai hak dan kewajiban yang seimbang dalam kehidupan rumah tangga. Dalam pergaulan hidup masyarakat, mereka tidak boleh saling mengekang dan menghalangi satu sama lain.

\section{Putusnya Perkawinan}

Istilah putus perkawinan dapat dimaksudkan juga penghentian atau pecahnya perkawinan, tiga istilah tersebut mempunyai pengertian dan makna yang sama. "Pecah" menurut artinya yaitu terbelah menjadi beberapa bagian, retak atau rekah, bercerai berai, sedangkan "Putus" berarti tidak berhubungan lagi, berpisah atau selesai, sedangkan "Henti" maksudnya tidak bisa berjalan lagi. ${ }^{1}$

Kitab Undang-Undang Hukum Perdata dalam Pasal 199 menentukan bahwa perkawinan dapat putus antara lain karena:

1. Kematian;

2. Kepergiaan suami atau istri selama 10 tahun dan diikuti dengan perkawinan baru dengan orang lain;

3. Putusan hakim setelah adanya perpisahan meja makan dan tempat tidur selama 5 tahun;

4. Perceraian.

Dalam poin kedua di atas, yang dimaksudkan dengan perpisahan meja makan dan tempat tidur adalah perpisahan antara suami istri yang tidak mengakhiri pernikahan, akibat yang terpenting adalah meniadakan kewajiban bagi suami istri untuk tinggal bersama, walau akibatnya dalam hukum harta benda adalah sama dengan perceraian. ${ }^{2}$ Dengan demikian, perkawinan belum menjadi bubar dengan adanya perpisahan meja dan tempat tidur. Alasan-alasan suami istri mengajukan perpisahan meja dan tempat tidur adalah:

\footnotetext{
${ }^{1}$ Tim Penyusun Kamus P3B, Kamus Besar Bahasa Indonesia, Jakarta: Balai Pustaka, 1990

${ }^{2}$ C. S. T. Kansil, Op. Cit., hlm. 109
} 
1. Semua alasan untuk perceraian, seperti zina, tinggalkan dengan sengaja, penghukuman, penganiayaan berat, perselisihan yang terus menerus, dan lain sebagainya. Hal ini diatur dalam Pasal 233 ayat (1) KUHPerdata;

2. Berdasarkan perbuatan-perbuatan yang melampaui batas, penganiayaan dan penghinaan kasar yang dilakukan oleh pihak yang satu kepada pihak yang lain. Hal ini diatur dalam Pasal 233 ayat (2) KUHPerdata;

Cara pengajuan, permohonan, pemeriksaan dan pemutusan hakim terhadap perpisahan meja dan tempat tidur adalah dengan cara yang sama seperti dalam hal perceraian (Pasal 234 KUHPerdata). Di samping itu, perpisahan meja dan tempat tidur ini dapat diajukan tanpa alasan dengan syarat perkawinan telah berjalan 2 tahun atau lebih, serta suami istri harus membuat perjanjian dengan akta otentik mengenai perpisahan diri mereka, penunaian kekuasaan orang tua, dan pemeliharaan serta pendidikan anak-anak mereka (Pasal 237 ayat (1) KUHPerdata).

Keputusan mengenai perpisahan meja dan tempat tidur harus diumumkan dalam Berita Negara. Selama pengumuman itu belum berlangsung, keputusan tidak berlaku bagi pihak ketiga (Pasal 245 KUHPerdata). Setelah mendengar dari keluarga suami istri dan keputusan pisah meja dan tempat tidur diucapkan oleh hakim, maka ditetapkan siap dari kedua orang tua itu yang akan menjalankan kekuasaan orang tua. Penetapan ini berlaku setelah keputusan perpisahan meja dan tempat tidur mempunyai kekuatan hukum (Pasal 246 KUHPerdata). Akibat dari perpisahan meja dan tempat tidur antara lain:

1. Suami istri dapat meminta pengakhiran perkawinan di muka pengadilan apabila perpisahan meja dan tempat tidur di antara mereka telah berjalan 5 tahun tanpa adanya perdamaian (Pasal 200 KUHPerdata);

2. Pembebasan dari kewajiban bertempat tinggal bersama;

3. Berakhirnya persatuan harta kekayaan (Pasal 243 KUHPerdata);

4. Berakhirnya kewenangan suami untuk mengurus harta kekayaan istri.

5. Perpisahan meja dan tempat tidur demi hukum menjadi batal apabila suami istri rujuk kembali dan semua akibat dari perkawinan antara suami istri hidup kembali namun semua perbuatan perdata dengan pihak ketiga selama perpisahan tetap berlaku (Pasal 248 KUHPerdata).

Undang-Undang Nomor 1 Tahun 1974 mengatur bahwa perkawinan dapat putus dikarenakan hal-hal sebagai berikut:

1. Kematian

2. Perceraian

3. Putusan Pengadilan

Putusnya perkawinan yang disebabkan karena kematian suami atau istri mengandung arti bahwa dengan kematian salah satu pihak, maka putuslah hubungan perkawinan di antara mereka dan pihak lain berhak mewaris atas harta peninggalan yang meninggal, ${ }^{3}$ namun harus diingat dalam hal suami yang

${ }^{3}$ Sudiman Kartohadiprodojo, Pengantar Tata Hukum di Indoensia, Jakarta: PT Pembangunan, 1997, hlm. 107. 
meninggal misalnya, walaupun dengan kematian itu tidak dimungkinkan hubungan mereka disambung lagi, bagi istri yang suaminya meninggal tidak boleh segera melaksanakan perkawinan baru dengan laki-lakin lain kecuali telah lewat jangka waktu yang ditentukan baik dalam ketentuan undang-undang maupun ketentuan agama dan kepercayaan masing-masing. Jangka waktu ini dinamakan jangka waktu tunggu. Pasal 39 PP Nomor 9 Tahun 1975 yang menyebutkan bahwa masa tunggu seorang janda adalah:

1. Apabila perkawinan putus karena kematian, waktu tunggu adalah 30 hari;

2. Apabila perkawinan putus karena perceraian, waktu tunggu bagi yang masing dating bukan ditetapkan 3 kali suci dengan sekurang-kurangnya 90 hari dan bagi tidak datang bulan ditetapkan 90 hari;

3. Apabila perkawinan putus sedang janda tersebut dalam keadaan hamil, waktu tunggu ditetapkan sampai melahirkan.

Menurut pasal yang sama, tidak ada waktu tunggu bagi janda yang putus perkawinan karena perceraian, sedang antara janda tersebut dan bekas suaminya belum pernah terjadi hubungan kelamin. Bagi perkawinan yang putus karena perceraian, tenggang waktu tunggu dihitung sejak jatuhnya putusan pengadilan yang mempunyai kekuatan hukum tetap, sedangkan bagi perkawinan yang putus karena kematian, tenggang waktu tunggu dihitung sejak kematian suami.

Perceraian adalah putusnya suatu perkawinan yang sah di depan hakim pengadilan berdasarkan syarat-syarat yang ditentukan oleh undang-undang. Oleh karena itu perlu dipahami jiwa dari peraturan mengenai perceraian tersebut serta akibat-akibat yang mungkin timbul setelah perkawinan di antara suami istri tersebut putus. Harus dipahami juga apa alasan-alasan yang mendasari putusnya perkawinan itu serta sebab-sebab terjadinya perceraian.

Maksud perkawinan adalah membentuk suatu keluarga yang kekal dan bahagia, artinya pikiran mereka suatu angan-angan untuk hidup bersama selamalamanya. Idealisme perkawinan lantas luntur, ada saja penyebabnya. Mungkin tidak terdapat lagi kesepakatan atau kerukunan antara suami istri, malah mungkin terjadi perselisihan yang berkepanjangan, walaupun telah diusahakan penyelesainnya, atau mungkin telah terjadi pertengkaran terus menerus atau pertentangan yang tidak mungkin didamaikan lagi.

\section{Pengertian Perceraian}

Perceraian merupakan suatu hal yang tidak bisa dipisahkan dari perkawinan, dikarenakan tidak ada perceraian tanpa diawali dengan perkawinan. Perkawinan merupakan awal dari hidup bersama antara seorang pria dengan seorang wanita yang diatur dalam peraturan perundang-undangan yang berlaku. Dalam semua tradisi hukum baik civil law, common law, maupun Islamic law, perkawinan adalah sebuah kontrak berdasarkan persetujuan sukarela yang bersifat pribdai antara seorang pria dan seorang wanita untuk menjadi suami istri. ${ }^{4}$ Dalam hal ini, perkawinan selalu dipandang sebagai dasar bagi unit keluarga yang mempunyai arti

${ }^{4}$ Wirjono Prodjodikoro, Op. Cit., hlm. 8 
penting bagi penjagaan moral atau akhlak masyarakat dan pembentukan peradaban. Hal ini dapat dilihat dari perumusan tujuan perkawinan untuk membentuk keluarga (rumah tangga) yang bahagia dan kekal berdasarkan Ketuhanan Yang Maha Esa, namun pada saat tujuan itu tidak tercapai, maka perceraian merupakan jalan keluar terakhir yang mesti ditempuh. Perceraian tidak dapat dilakukan kecuali telah ada alasan-alasan yang dibenarkan oleh agama dan undang-undang.

Pasal 38 Undang-Undang Nomor 1 Tahun 1974 menyatakan bahwa pada perjalanannya, perkawinan dapat saja berakhir, yaitu jika disebabkan oleh kematian, perceraian atau atas keputusan pengadilan. Secara ringkas perceraian adalah penghapusan perkawinan dengan putusan hakim atau tuntutan salah satu pihak dalam perkawinan tersebut. ${ }^{5}$ Dalam Pasal 208 KUHPerdata dinyatakan bahwa perceraian atas persetujuan suami/istri tidak diperkenankan sedangkan UndangUndang Nomor 1 Tahun 1974 mengenai Perkawinan pada dasarnya menganut asasasas untuk mempersulit terjadinya perceraian, walaupun bukan berarti menutup atau mengunci mati pintu perceraian.

\section{Alasan-Alasan Pengajuan Gugatan Perceraian}

Perceraian tidak dapat terjadi begitu saja di mata hukum, artinya harus ada alasan yang dibenarkan oleh hukum untuk melakukan sebuah perceraian. Itu sangat mendasar, terutama bagi pengadilan yang notabene berwenang memutuskan apakah sebuah perceraian layak atau tidak untuk dilaksanakan. Termasuk segala keputusan yang menyangkut konsekuensi terjadinya perceraian, juga sangat ditentukan oleh alasan melakukan perceraian. Menurut Kitab Undang-Undang Hukum Perdata, alasan-alasan yang dapat dipakai agar permintaan perceraian berhasil antara lain adalah:

1. Zina. Perlu diketahui bahwa zina menurut Kitab Undang-Undang Hukum Perdata berlainan atau berbeda dengan zina menurut Hukum Islam. Definisi zina menurut KUHPerdata adalah hubungan kelamin dengan orang lain daripada suami atau istrinya. Jadi, menurut KUHPerdata orang tidak menikah atau tidak mempunyai suami atau istri tidak berzina, apabila ia mengadakan hubungan kelamin dengan seseorang yang tidak menikah. ${ }^{6}$

2. Meninggalkan tempat bersama dengan itikad jahat. Itikad jahat di sini maksudnya adalah meninggalkan tempat tinggal bersama dan tetap menolak kembali ke tempat kediaman bersama tanpa alasan cukup selama 5 tahun. Jangka waktu 5 tahun berlaku mulai dari saat meninggalkan tempat tinggal bersama atau dari saat seseorang semula meninggalkan tempat tinggal bersama dengan alasan sah dan alasan dah itu sudah berakhir.

3. Mendapat hukuman penjara 5 tahun atau lebih dalam suatu keputusan hakim yang diucapkan selama pernikahan, maksud dari pembuat undangundang ini adalah seorang tidak wajib tetap terikat dengan seorang kriminil atau penjahat yang telah diadili. Suatu keputusan hukuman yang diambil di luar negeri juga dapat dipakai sebagai alasan permohonan perceraian.

\footnotetext{
${ }^{5}$ Abdulkadir Muhammad, Hukum Perdata Indonesia, Bandung: Citra Aditya Bakti, 1993, hlm. 109
}

${ }^{6}$ C. S. T. Kansil, Modul Hukum Perdata, Jakarta: Pradnya Paramita, 2000, hlm. 107. 
4. Melukai berat atau menganiaya, yang dilakukan oleh suami terhadap istri atau sebaliknya, dengan demikian sehingga membahayakan jiwa korban atau sehingga korban memperoleh luka-luka yang membahayakan. Hal ini diatur dalam Pasal 209 KUHPerdata. ${ }^{7}$

5. Keretakan yang tidak dapat dipulihkan, yang merupakan hasil dari yurisprudensi yang ada.

Menurut Undang-Undang Nomor 1 Tahun 1974 dalam Pasal 39, perceraian hanya dapat dilakukan di depan sidang pengadilan setelah pengadilan yang bersangkutan berusaha dan tidak berhasil mendamaikan kedua belah pihak. Untuk melakukan perceraian harus ada cukup alasan bahwa antara suami istri tersebut tidak akan dapat hidup rukun sebagai suami istri. Adapun alasan-alasan yang dapat dijadikan dasar untuk perceraian menurut undang-undang perkawinan ini seperti diatur dalam Peraturan Pemerintah Nomor 9 Tahun 1975 tentang Pelaksanaan Undang-Undang Nomor 1 Tahun 1974 antara lain: ${ }^{8}$

1. Salah satu pihak berbuat zina atau menjadi pemabuk, pemadat, penjudi dan lain sebagainya yang sukar disembuhkan. Alasan ini dapat digunakan untuk mengajukan gugatan perceraian, karena bila seseorang telah berbuat zina berarti dia telah melakukan pengkhianatan terhadap kesucian dan kesakralan suatu perkawinan. Perbuatan-perbuatan ini merupakan pelanggaran terhadap hukum agama dan hukum positif, namun harus dilihat, seorang suami yang telah mabuk dalam sebuah kafe namun dia hanya berbuat hal tersebut satu dan karena terpengaruh oleh kawannya tentulah belum merupakan alasan untuk bercerai.

2. Salah satu meninggalkan yang lain selama 2 (dua) tahun berturut-turut tanpa izin pihak lain dan tanpa alasan yang sah atau karena hal lain di luar kemampuan. Hal ini terkait dengan kewajiban memberikan nafkah baik lahir maupun batin, yang bila kemudian salah satu pihak meninggalkan pihak lain dalam waktu lama tanpa seijin pasangannya tersebut, maka akan berakibat pada tidak dilakukannya pemenuhan kewajiban yang harus diberikan kepada pasangannya, sehingga bila pasangannya kemudian tidak rela, maka dapat mengajukan alasan tersebut untuk menjadi dasar diajukannya gugatan perceraian di pengadilan, namun tentu alasan tersebut harus benar-benar diteliti kebenarannya.

3. Salah satu pihak mendapat hukuman penjara 5 (lima) tahun atau hukuman yang lebih berat setelah perkawinan berlangsung. Hampir sama dengan alasan di poin sebelumnya, poin ini juga dapat dijadikan sebagai alasan oleh salah satu pihak untuk mengajukan gugatan perceraian. Sebab jika salah satu pihak sedang menjalani hukuman penjara 5 (lima) tahun atau lebih, itu berarti yang bersangkutan tidak dapat menjalankan kewajibannya sebagai seorang suami/istri.

4. Salah satu pihak melakukan kekejaman atau penganiayaan berat yang membahayakan terhadap pihak lain. Contoh: seorang suami telah memukul

\footnotetext{
${ }^{7}$ Riduan Syahrani, Seluk Beluk dan Asas-Asas Hukum Perdata, Bandung: Alumni, 2000, hlm. 43.

${ }^{8}$ Riduan Syahrani, Buku Materi Dasar Hukum Acara Perdata, Bandung: Citra Aditya Bakti, 2008, hlm. 115.
} 
kepala istrinya dengan besi, sehingga gegar otak dan perbuatan tersebut membahayakan kelangsungan hidupnya. Perbuatan demikian sudah cukup menjadi alasan untuk perceraian di pengadilan. Poin ini menitikberatkan pada kemaslahatan atau manfaat dari perkawinan, dibandingkan dengan keselamatan individu/salah satu pihak. Bila suatu perkawinan tetap dipertahankan namun akan berdampak pada keselamatan individu, maka akan lebih baik jika perkawinan tersebut diputus dengan perceraian. Dalam hal ini harus benar-benar bisa dibuktikan mengenai tindakan atau ancaman yang membahayakan keselamatan seseorang/salah satu pihak. Dengan demikian, alasan tersebut dapat diterima oleh majelis hakim pemeriksa perkara di pengadilan.

5. Salah satu pihak mendapat cacat badan atau penyakit yang mengakibatkan tidak dapat menjalankan kewajibannya sebagai suami/istri. Tidak dapat dipungkiri bila ikatan perkawinan dipengaruhi faktor-faktor jasadiah, terutama masalah kebutuhan biologis.

6. Antara suami/istri terus meneris terjadi perselisihan dan pertengkeran dan tidak ada harapan akan hidup rukun lagi dalam rumah tangga. Contoh: suami istri bertengkar tentang mendidik anak, cara mengajar anak, belum menjadi alasan untuk mengajukan gugatan perceraian, tetapi jika salah satu pihak telah melakukan perselingkuhan, maka patut dijadikan alasan untuk melakukan gugatan perceraian. Tidak ada kehidupan rumah tangga yang rukun, tentram dan nyaman apabila dipenuhi dengan perselisihan. Apalagi, bila pertengkaran tersebut tidak terelakan dan tak terselesaikan. Jika hal itu berlangsung terus menerus dan dapat menimbulkan dampak buruk yang lebih besar ke depan, maka diperbolehkan mengajukan gugatan perceraian kepada pengadilan.

Dari penjabaran di atas, dapat dilihat bahwa perceraian hanya dapat dilakukan apabila telah memenuhi salah satu dari seluruh alasan di atas. Dalam Pasal 39 ayat (2) Undang-Undang Nomor 1 Tahun 1974 tentang Perkawinan, disebutkan bahwa untuk melakukan perceraian harus ada alasan yang dapat membuktikan bahwa pasangan suami-istri tidak dapat lagi hidup rukun sebagaimana mestinya. ${ }^{9}$ Ketika upaya perceraian sudah bulat hendak dilaksanakan, maka pemilihan alasan, terlepas dari alasan yang sesungguhnya sangat menentukan proses terjadinya perceraian. Serta akibat hukum dari perceraian itu sendiri.

\section{Pengertian Verstek}

Mengenai pengertian verstek, tidak terlepas kaitannya dengan fungsi beracara dan putusan atas perkara yang disengketakan, yang memberi wewenang kepada hakim menjatuhkan putusan tanpa hadirnya satu pihak. Diajukannya gugatan merupakan kepentingan penggugat sehingga diharapkan hadir pada hari sidang yang telah ditetapkan.

\footnotetext{
${ }^{9}$ Lilik Rasyidi, Alasan Perceraian Menurut Undang-Undang Nomor 1 Tahun 1974 tentang Perkawinan, Bandung: Alumni, 1989, hlm. 15
} 
Pada saat persidangan, ada kemungkinan salah satu pihak tidak hadir. Apabila pihak penggugat yang tidak hadir meski telah dipanggil secara sah dan patut, sedangkan tergugat hadir maka perkara dapat diputus. Dalam hal ini gugatan penggugat dinyatakan gugur serta dihukum untuk membayar biaya perkara (vide Pasal 124 HIR / Pasal 148 RBg). Sebaliknya, jika tergugat tidak hadir meskipun telah dipanggil secara sah dan patut, maka hakim dapat menjatuhkan putusan tanpa hadirnya tergugat (verstek) (vide Psal $125 \mathrm{HIR}$ / Pasal $149 \mathrm{RBg}$ ).

Adapun pengertian verstek menurut Yahya Harahap adalah "Pemberian wewenang kepada hakim untuk memeriksa dan memutus perkara meskipun penggugat atau tergugat tidak hadir di persidangan pada hari dan tanggal yang ditentukan. Dengan demikian putusan diambil dan dijatuhkan tanpa bantahan dan sanggahan dari pihak yang tidak hadir." Sedangkan menurut Soepomo verstek adalah pernyataan bahwa tergugat tidak hadir meskipun menurut hukum acara ia harus datang. Verstek hanya dapat dinyatakan jikalau tergugat tidak hadir pada hari sidang pertama.

\section{Ketidakhadiran Tergugat Dalam Penjatuhan Putusan Verstek Dalam Putusan Nomor 62/Pdt.G/2017/PN.JKT.UTR}

Proses penyelesaian perkara perdata melalui jalur pengadilan diawali dengan pengajuan gugatan oleh pihak yang merasa haknya terganggu atau dirugikan oleh pihak lain. Gugatan merupakan titik dasar penanganan perkara karena menjadi acuan pemeriksaan dalam beracara di depan persidangan. Penggugat yang hendak mengajukan gugatan harus mempunyai kepentingan hukum yang cukup dan memiliki dasar hukum yang jelas untuk menuntut haknya. Dalam Yurisprudensi Mahkamah Agung Republik Indonesia Tanggal 7 Juli 1971, Reg No. 294 K/Sip/1971 juga mensyaratkan bahwa gugatan harus diajukan oleh orang yang mempunyai hubungan hukum. ${ }^{10}$

Pada umumnya, masyarakat pencari keadilan yang datang ke Pengadilan adalah masyarakat yang awam tentang hukum. Oleh karena itu, para pencari keadilan yang datang ke pengadilan hampir seluruhnya dalam menyampaikan gugatan atau permohonan tidak dengan surat gugatan atau permohonan yang dibuat sesuai standar surat gugatan atau permohonan sesusai ketentuan hukum acara. ${ }^{11}$ Dalam menghadapi masyarakat mencari keadilan semacam ini, sesuai asas peradilan: Pengadilan membantu para pencari keadilan dan berusaha sekeraskerasnya mengatasi segala hambatan dan rintangan untuk tercapainya peradilan sederhana, cepat dan biaya ringan. Pengadilan berkewajiban membantu para pencari keadilan untuk memberikan arahan-arahan tentang bagaimana caranya membuat surat gugatan atau permohonan yang benar menurut ketentuan yang berlaku. Dalam hal pencari keadilan dimaksud buta huruf, tidak dapat membaca dan menulis, gugatannya harus disampaikan secara lisan kepada Ketua Pengadilan, dan Ketua Pengadilan dapat melimpahkan kekuasannya tersebut kepada hakim lain

\footnotetext{
${ }^{10}$ Darwin Prints, Strategi Menyusun dan Menangani Gugatan Perdata, Bandung: PT. Citra Aditya Bakti, 2002, hlm. 3.

${ }^{11}$ Taufik Hamami, Kedudukan dan Eksistensi Pengadilan Agama dalam Sistem Tata Hukum di Indonesia, Bandung: PT. Alumni, 2003, hlm. 135.
} 
guna merumuskan gugatan lisan tersebut ke dalam surat gugatan atau permohonan. Surat gugatan atau permohonan harus ditandatangani oleh pihak penggugat atau pemohon atau ditandatangani oleh kuasanya/wakilnya bila perkara tersebut dikuasakan atau diwakilkan kepada orang lain, namun untuk perkara gugatan/permohonan yang diajukan secara lisan (penggugat/pemohon yang buta huruf), surat gugatan/permohonan tersebut ditandatangani oleh Ketua Pengadilan/Hakim yang merumuskan surat gugatan/permohonan tersebut. Gugatan/permohonan yang telah memenuhi persyaratan setelah didaftarkan pada kepaniteraan kemudian disampaikan kepada Ketua Pengadilan guna menunjuk Majelis Hakim yang ditugaskan untuk memeriksa dan mengadili perkara tersebut.

Setelah Ketua Pengadilan menerima berkas perkara dari panitera dan membentuk Majelis Hakim, maka penyerahan berkas kepada Majelis Hakim pun harus dilakukan dengan cepat, paling lambat 7 (tujuh) hari dari tanggal penetapan Majelis, karena Majelis harus segera pula menetapkan hari sidang dan jangka waktu penerbitan penetapan hari sidang disesuaikan dengan kondisi para pihak berperkara. Untuk yang diketahui alamat/tempat kediamannya di Indonesia, selambatlambatnya 30 hari sejak perkara tersebut terdaftar di Kepaniteraan. Untuk yang berada di luar negeri, tenggat waktunya sekurang-kurangnya 6 (enam) bulan dan untuk yang tidak diketahui tempat kediamannya tenggang waktunya sekurangkurangnya 4 (empat) bulan sejak perkara tersebut terdaftar di Kepaniteraan Pengadilan.

Setelah melampaui tahap pengajuan gugatan, pembayaran biaya, registrasi perkara, penetapan majelis hingga penetapan hari sidang, maka tahap selanjutnya adalah tindakan pemanggilan pihak tergugat untuk hadir di depan persidangan. Peristiwa yang ditemui oleh juru sita atau juru sita pengganti menyampaikan panggilan, apakah ia bertemu langsung dengan yang dipanggil atau tidak, atau apa yang dikatakan oleh yang dipanggil maupun umpamanya bagaimana cara penyampaian panggilannya harus dicatat dalam berita acara (relaas) panggilan kepada Ketua Majelis Hakim yang akan memeriksa perkara tersebut sebagai bukti bahwa para pihak telah dipanggil.

Dalam perkara dengan putusan Nomor 62/PDT.G/2017/PN.JKT.UTR, Nyonya Ngui Fanny Rawati mengajukan gugatan perceraian terhadap suaminya yang bernama Hendri dengan pokok gugatan bahwa di dalam kehidupan perkawinan antara Penggugat dan Tergugat sempat berlangsung dengan baik dan harmonis, walaupun kadang kala diwarnai dengan kesalahpahaman, keributan dan pertengkaran-pertengkaran kecil, yang mana hal ini adalah sesuatu yang lumrah terjadi dalam kehidupan rumah tangga dan dapat diselesaikan dengan baik.

Keadaan semakin diperparah dengan tuduhan dari Tergugat terhadap Penggugat yang sering pulang malam dari kantor dikarenakan Penggugat selingkuh, padahal tidak pernah ada orang ketiga dalam kehidupan rumah tangga Penggugat dan Tergugat. Tergugat yang terus menerus berpikiran negatif dan merasa insecure dengan keadaannya sendiri membuat perkawinan antara Tergugat dan Penggugat yang semula indah dan harmonis mulai menjadi tidak harmonis dan penuh dengan riak dan gelombang ketidak serasian dan ketidak cocokan yang semakin parah, dan sudah sulit untuk didamaikan kembali walaupun telah diusahakan. Selanjutnya pertengkaran antara Penggugat dan Tergugat terjadi setiap hari sehingga pada akhirnya pada pertengah tahun 2014 Penggugat sudah tidak tahan lagi untuk tinggal 
bersama dengan Tergugat dan memilih untuk kembali ke rumah orang tua Penggugat dengan membawa serta kedua anak mereka.

Tergugat masih mencoba untuk mendatangi Penggugat beberapa kali dengan datang ke kantor Penggugat hingga akhirnya Tergugat berhenti menganggu dan menghilang dari kehidupan Penggugat sampat saat ini, dan Penggugat juga sudah tidak lagi mengetahui di mana rimbanya Tergugat, namun dikarenakan Penggugat membutuhkan kepastian hukum terhadap status penikahannya maka dengan memperhatikan ketentuan Pasal 38 Undang-Undang Nomor 1 Tahun 1974 jo Pasal 19 huruf (f) Peraturan Pemerintah Nomor 9 Tahun 1975, Penggugat memohon kepada Pengadilan Negeri Jakarta Utara untuk memberikan putusan dan menyatakan menurut hukum bahwa perkawinan antara Penggugat dan Tergugat putus karena perceraian dan dengan segala akibat hukumnya.

Penggugat datang menghadap sendiri ke persidangan. Tergugat tidak datang menghadap dan tidak pula menyurug orang lain menghadap sebagai wakilnya, meskipun telah dilakukan pemanggilan secara resmi dan patut. Keberadaan tergugat yang tidak lagi diketahui keberadaannya membuat Pengadilan melakukan pemanggilan melalui media massa, namun Tergugat tetap tidak hadir di persidangan. Pada satu sisi, undang-undang mendudukan kehadiran Tergugat pada persidangan sebagai hak, bukan kewajiban yang bersifat imperatif. Hukum menyerahkan sepenuhnya, apakah tergugat mempergunakan hak itu untuk membela kepentingannya. Di sisi lain, undang-undang tidak memaksakan penerapan acara verstek secara imperatif. Hakim tidak harus menjatuhkan putusan verstek terhadap Tergugat yang tidak hadir memenuhi panggilan. Penerapannya bersifat fakultatif. Kepada Hakim diberi kebebasan untuk menerapkannya atau tidak. Sifat penerapan yang fakultatif tersebut, diatur dalam Pasal 126 HIR sebagai acuan: ${ }^{12}$

Berdasarkan hasil penelitian yang telah dilakukan, maka putusan verstek itu dapat dijatuhkan ketika pada hari persidangan yang telah ditetapkan oleh Pengadilan, Penggugat datang menghadap sendiri ke persidangan sedangkan Tergugat tidak pernah datang dan tidak menyuruh orang lain atau wakilnya menghadap di muka persidangan sebagai kuasanya, padahal telah dipanggil secara sah dan patut. Berdasarkan ketentuan Pasal 125 ayat (1) HIR dan Pasal 149 ayat (1) $\mathrm{TBg}$, yaitu putusan yang dijatuhkan tanpa hadirnya Tergugat dapat dikabulkan sepanjang berdasarkan hukum dan beralasan. Putusan verstek dapat dijatuhkan apabila sudah memenuhi salah satu alasan perceraian sebagaimana yang tertuang dalam Pasal 19 Peraturan Pemerintah Nomor 9 Tahun 1975. Alasan lain penjatuhan putusan verstek dalam Putusan Nomor 62/Pdt.G/2017/PN Jkt. Utr adalah Tergugat telah dipanggil secara sah dan patut, namun Tergugat tidak datang atau tidak menyuruh seseorang menghadap ke persidangan sebagai kuasanya. Sehingga Penulis berpendapat bahwa acara ketidakhadiran Tergugat dalam hal penjatuhan putusan verstek telah sesuai dengan hukum yang berlaku.

${ }^{12}$ M. Yahya Harahap, Hukum Acara Perdata, hlm. 388-389. 


\section{Pertimbangan Hakim Dalam Memutus Cerai Melalui Putusan Verstek Dalam Putusan Nomor 62/Pdt.G/2017/PN Jakarta Utara}

Diajukannya suatu perkara di Pengadilan khusus perkara perceraian oleh Penggugat adalah bertujuan untuk mendapatkan keputusan yang adil dan obyektif. Putusan merupakan tahapan akhir dalam beracara di Pengadilan. Sidang dengan agenda pembacaan putusan sangat ditunggu-tunggu oleh para pihak yang berperkara baik Tergugat terlebih pihak Penggugat, sebab putusan tersebut akan memberikan kepastian hukum dan keadilan terhadap perkara yang telah diperiksa di depan persidangan. Setelah proses pemeriksaan perkara di persidangan dilaksanakan, hakim akan menjatuhkan putusan berdasarkan apa yang dituntut oleh pihak penggugat. Berdasarkan Pasal 14 ayat (1) Undang-Undang Kekuasaan Kehakiman, putusan diambil berdasarkan sidang permusyawaratan Hakim yang bersifat rahasia, kemudian dalam Pasal 53 ayat (1) diatur bahwa dalam memeriksa dan memutus perkara, hakim bertanggung jawab atas penetapan dan putusan yang dibuatnya.

Sehubungan dengan penyusunan putusan dimaksud dalam rangka mengakhiri suatu pekara, ada tiga hal yang amat penting harus diperhatikan dan dipahami dalam penyususnan putusan tersebut. Meskipun pada dasarnya betapa sulitnya pemenuhan ketiga hal tersebut, majelis hakim berusaha semaksimal mungkin agat putusan yang disusunnya memenuhi ketiga hal dimaksud, agar tidak terjadi suatu keresahan dan kekacauan dalam kehidupan masyarakat akibat putusan yang disusunnya. Ketiga hal dimaksud adalah keadilan, kepastian dan kemanfaatan. Putusan harus adil, mempunyai kepastian hukum dan bermanfaat bagi kedua belah pihak dan masyarakat.

Sebelum memutus perkara dengan verstek biasanya hakim mempertimbangkan dari keabsahan panggilan yang disampaikan kepada Tergugat dan alasan ketidakhadirannya. Kemudian hakim memeriksa kesesuaian antara posita dan petitum Penggugat serta gugatan tersebut beralasan atau tidak. Jika gugatan itu tidak beralasan, yaitu apabila tidak diajukan peristiwa-peristiwa yang membenarkan tuntutan, maka gugatan akan ditolak. Hal inilah yang dilakukan oleh Majelis Hakim dalam perkara perceraian dengan Putusan Nomor 62/Pdt.G/2017/PN Jkt.Utr. di mana Hakim mempertimbangkan berdasarkan Peraturan Mahkamah Agung RI Nomor 1 Tahun 2008 tentang Mediasi, maka perkara ini seharusnya melalui tahapan mediasi, tetapi dikarenakan tergugat tidak pernah hadir dalam persidangan, maka mediasi di antara Penggugat dan Tergugat tidak dapat dilakukan.

Tergugat tidak pernah hadir dalam dalam persidangan dan tidak pernah menyuruh orang lain datang menghadap sebagai wakil/kuasanya dan juga tidak mengirim surat tentang ketidak hadirannya, sekalipun telah dipanggil secara resmi dan patut, maka dengan ketidak hadiran Tergugat dianggap telah mengakui semua dalil gugatan Penggugat dan perkaranya dapat diputus dengan Verstek sesuai dengan ketentuan Pasal 149 ayat (1) R.Bg dan Pasal 150 R. Bg. Pertimbangan hukumnya yang berdasarkan Peraturan Mahkamah Agung RI Nomor 1 Tahun 2008 tentang Mediasi, maka perkara tersebut tidak dapat di mediasi karena Tergugat tidak pernah hadir dalam persidangan. Penulis juga menyetujui dengan adanya putusan verstek sesuai ketentuan Pasal 149 ayat (1) R.Bg dan Pasal 150 R.Bg dikarenakan Tergugat tidak pernah hadir dalam persidangan dan juga tidak menyuruh orang lain datang menghadap sebagai wakil/kuasanya dan juga tidak mengirim surat tentang ketidak hadirannya, sekalipun telah dipanggil secara resmi dan patut, maka dengan 
ketidak hadiran Tergugat dianggap telah mengakui semua dalil gugatan Penggugat dan perkaranya diputus dengan verstek.

Majelis Hakim berpendapat bahwsa dengan berdasarkan pada keterangan saksi 1 dan 2 dari Penggugat yang saling berkesesuaian satu sama lain, sesuai pula dengan fakta tentang Penggugat dan anak-anaknya sudah tinggal bersama dalam satu rumah dengan orang tua Penggugat tersebut, ternyata bahwa telah terjadi percekcokan yang terus menerus antara Penggugat dan Tergugat bahkan Tergugat pernah memukul Penggugat sehingga Penggugat dengan membawa anak-anaknya telah pulang ke rumah orang tua Penggugat sejak tahun 2014. Penyebab percekcokan tersebut karena Tergugat cemburu dengan Penggugat dan menuduh Penggugat telah melakukan perselingkuhan dengan teman sekantornya, selain itu juga Tergugat tidak memberikan nafkah yang mencukupi untuk Penggugat dan anak-anaknya, bahkan setelah Penggugat kembali ke rumah orang tuanya selama 3 tahun, Tergugat tidak pernahlagi mengunjungi dan memberi nafkah atau keperluan biaya pendidikan kepada 2 orang anaknya, dengan demikian Penggugat telah berhasil membuktikan dalil-dalil gugatannya tentang telah terjadi percekcokan terus menerus dan tidak dapat diharapkan untuk hidup rukun dan bahagia lagi yang mana hal tersebut merupakan salah satu alasan terjadinya perceraian sesuai dengan Pasal 38 Undang-Undang Nomor 1 Tahun 1974 jo. Pasal 19 huruf (f) Peraturan Pemerintah Tahun 1975 tentang Perkawinan.

Gugatan Penggugat dapat dikabulkan tentang terjadinya perceraian, demikian pula mengenai hak asuh terhadap kedua anak mereka ditentukan dalam perkara ini, bahwa kehidupan kedua orang anak tersebut tetap menjadi tanggung jawab bersama Penggugat dan Tergugat sepenuhnya atau secara bersama-sama tetapi karena Tergugat sudah tidak pernah hadir di persidangan, maka hak asuh terhadap kedua anak tersebut diputuskan diserahkan sepenuhnya kepada Penggugat sejak putusan perkara ini berkekuatan hukum tetap sampat dengan kedua anak tersebut dewasa dan mandiri, dan memberikan pula hak kepada Tergugat untuk dapat mengunjungi kedua anak tersebut secara baik.

Dengan mempertimbangkan Undang-Undang Nomor 1 Tahun 1974 tentang Perkawinan, dan Peraturan Pemerintah Nomor 9 Tahun 1975 tentang Peraturan Pelaksanaan Undang-Undang Nomor 1 Tahun 1974 tentang Perkawinan Pasal 19 huruf (f), dan segala ketentuan undang-undang dan peraturan lain yang berkenaan dengan perkara ini, maka Majelis Hakim memutuskan:

1 Menyatakan bahwa tergugat telah dipanggil secara sah dan patut, tetapi tetap tidak hadir di Persidangan;

2 Mengabulkan gugatan Penggugat untuk sebagian dengan verstek;

3 Menyatakan perkawinan antara Penggugat dan Tergugat sebagaimana tertuang dalam kutipan Akna Perkawinan Nomor 116/I/2006 yang dikeluarkan oleh Dinas Kependudukan dan Catatan Sipil Propinsi DKI Jakarta tertanggal 27 Juni 2006 putus karena perceraian dan dengan segala akibat hukumnya;

4 Memberikan hak kepada Penggugat untuk mengasuh 2 (dua) orang anak dari perkawinan Penggugat dan Tergugat, sampai anak-anak tersebut dewasa dan mandiri, yaitu bernama:

a. Neville Abelova, yang lahir di Jakarta pada tanggal 30 Mei 2007;

b. Flossie Anabelova, yang lahir di Jakarta pada Tanggal 21 April 2010 
1. Memerintahkan panitera/sekretaris Pengadilan Negeri Jakarta Utara atau pejabat yang ditunjuk untuk itu agar mengirimkan 1 (satu) eksemplar copy putusan tersebut yang telah mempunyai kekuatan hukum yang tetap dan pasti dan memerintahkan kepada pejabat Kantor Catatan Sipil Propinsi DKI Jakarta untuk mencatatkan perceraian tersebut ke dalam buku Register yang sedang berjalan dan disediakan untuk itu dan menerbitkan Akta Perceraiannya;

2. Menghukum Tegugat untuk membayar seluruh biaya perkara ini, yang sampai saat ini tercatat sejumlah Rp. 3.326.000,- (tiga juta tiga ratus dua puluh enam ribu rupiah).

Dalam hal ini hakim wajib menegakan hukum dan keadilan berdasarkan Pancasila dengan menafsirkan hukum dan mencari dasar-dasar serta asas-asas yang menjadi landasannya, melalui perkara-perkara yang dihadapkan kepadanya sehingga keputusannya mencerminkan perasaan keadilan bangsa dan rakyat Indonesia. ${ }^{13}$ Hakim dalam menyelesaikan perkara yang diajukan kepadanya wajib memperhatikan dengan sungguh-sungguh nilai-nilai yang hidup dalam kehidupan masyarakat, sehingga putusannya sesuai dengan rasa keadilan. ${ }^{14}$

Secara umum yang menjadi dasar pertimbangan hakim dalam menjatuhkan putusan verstek adalah Pasal 125 HIR / Pasal 149 RBg, yaitu karena tergugat tidak pernah datang menghadap di muka persidangan setelah dipanggil secara resmi dan patut dan ketidakhadiran itu ternyata tidak disebabkan karena suatu alasan yang sah menurut hukum, serta gugatan Penggugat tidak melawan hukum dan beralasan, maka Tergugat harus dinyatakan tidak hadir.

Dari segi non yuridis, bahwa setelah dilakukan pemanggilan secara patut terhadap Tergugat, dan Tergugat tidak hadir, maka hakim berpendapat bahwa Tergugat telah mengakui semua alasan-alasan yang diajukan oleh Penggugat dan menganggap telah melepaskan haknya yang artinya bahwa Tergugat menyerahkan sepenuhnya kepada hakim serta melihat dari faktanya atau peristiwa dari dalil-dalil yang telah dibuktikan oleh Pemohon, sehingga tepatlah bila hakim memutus verstek perkara tersebut.

\section{KESIMPULAN}

Pelaksanaan acara ketidakhadiran Tergugat dalam hal penjatuhan putusan verstek perkara perceraian dengan Putusan Nomor 62/Pdt.G/2017/PN Jakarta Utara, telah sesuai dengan ketentuan Perundang-undangan yang berlaku, dapat dilihat sejak dari masuknya gugatan, proses pemanggilan, proses persidangan sampai acara pembuktian hingga berakhir dengan putusan verstek oleh hakim.

Tergugat tidak pernah hadir dalam persidangan sehingga Majelis Hakim berpendapat Tergugat telah melepaskan hak jawabnya dan dianggap mengakui seluruh dalil gugatan Pemohon. Secara umum yang menjadi dasar pertimbangan hakim dalam menjatuhkan putusan verstek adalah Pasal 125 HIR/Pasal 149 RBg,

${ }^{13}$ Undang-Undang Nomor 48 Tahun 2009 tentang Ketentuan-Ketentuan Pokok Kekuasaan Kehakiman

${ }^{14}$ Mukti Arto, Praktek Perkara Perdata Pada Peradilan Agama, Cetakan 6, Yogyakarta: Pustaka Pelajar, 2005, hlm. 35 
yaitu karena tergugat tidak pernah datang menghadap di Persidangan setelah dipanggil secara resmi dan patut dan ketidakhadirannya itu ternyata tidak disebabkan karena suatu alasan yang sah menurut hukum, serta gugatan Pemohon tidak melawan hukum dan beralasan maka Tergugat harus dinyatakan tidak hadir oleh karena itu, maka putusan atas perkara ini dapat dijatuhkan tanpa hadirnya Tergugat.

\section{SARAN}

1. Majelis hakim harus memperhatikan dengan seksama alasan ketidakhadiran dari salah satu pihak yang bersengketa dalam persidangan, jangan sampai ketidakhadiran salah satu pihak terutama dalam hal ini adalah Tergugat dijadikan suatu cara yang digunakan oleh para pihak yang bersengketa untuk menyelesaikan perkara dengan cepat.

2. Seorang hakim wajib hukumnya untuk mengusahakan mediasi dan perdamaian antara penggugat dan tergugat sebelum meneruskan persidangan. Hakim juga berhak memanggil anggota-anggota keluarga penggugat dan tergugat untuk didengar keterangannya mengenai perselisihan antara penggugat dan tergugat agar dapat memberikan keputusan yang seadil-adilnya.

\section{DAFTAR PUSTAKA}

\section{Buku}

Abbas, Syahrizal. Mediasi Dalam Perspektif Hukum Syariah, Hukum Adat dan Hukum Nasional. Jakarta: Kencana Prenada Media. 2009. . Mediasi dalam Perspektif Islam. Jakarta: Kencana. 2009

Anshori, Abdul Ghofur dan Yulkarnain Harahap. Hukum Islam: Dinamika dan Perkembangannya di Indonesia. Yogyakarta: Kreasi Total Media. 2008

Bachtiar, A. Menikahlah, Maka Engkau Akan Bahagia. Yogyakarta: Saujana. 2004.

Basyir, Ahmad Ajhar. Hukum Perkawinan Islam. Yogyakarta: UII Press. 2000.

Damanhuri, H. A. Segi-Segi Hukum Perjanjian Perkawinan Harta Bersama. Bandung: Mandar Maju. 2007.

Fajar, A. Mukhti. Tentang dan Sekitar Hukum Perkawinan di Indonesia. Malang: Fakultas Hukum Universitas Brawijaya. 1994.

Ghanim, Shaleh. Jika Suami Istri Berselisih: Bagaimana Mengatasinya?. Jakarta: Gema Insani Press. 1988.

Hadikusuma, Hilman. Hukum Perkawinan Indonesia Menurut Perundangan Hukum Adat, Hukum Agama. Jakarta: Mandar Maju, 2007.

Head, Jhon W. Pengantar Umum Hukum Ekonomi. Jakarta: Proyek ELIPS. 1997.

Ihromi, T. O. Bunga Rampai Sosiologi Keluarga. Jakarta: Yayasan Obor Indonesia. 1999.

Irianto, Sulistyowati. Perempuan dan Hukum. Jakarta: Yayasan Obor Indonesia. 2006. 
Jehani, Libertus. Perkawinan, Apa Resiko Hukumnya?. Jakarta: Forum Sahabat. 2008.

Kartohadiprodojo, Sudiman. Pengantar Tata Hukum di Indonesia. Jakarta: PT. Pembangunan. 1997.

Luhulima, Achie Sudiarti. Bahan Ajar Tentang Hak Perempuan. Jakarta: Yayasan Obor Indonesia. 2007.

Marzuki, Peter Mahmud. Penelitian Hukum. Jakarta: Kencana. 2006.

Mintarja, Endang. Menikahlah Denganku Atas Nama Cinta Ilahi. Jakarta: Qultum Media. 2005.

Muhammad, Abdulkadir. Hukum dan Penelitian Hukum. Bandung: PT. Citra Aditya Bhakti. 2004.

P, Martiman. Hukum Perkawinan Indonesia. Jakarta: Center Publishing. 2002

Prawirohamidjojo, Soetojo, dkk. Hukum Orang dan Keluarga. Cetakan Kesebelas. Bandung: Alumni.

Prodjohamidjodjo, MR. Martiman. Hukum Perkawinan Indonesia. Jakarta: Indonesia Legal Center Publishing. 2007.

Prodjodikoro, Wirjono. Hukum Perkawinan di Indonesia. Bandung: Sumur Bandung. 1981.

Rasyidi, Lilik. Alasan Perceraian Menurut Undang-Undang Nomor 1 Tahun 1974 tentang Perkawinan. Bandung: Alumni. 1989.

Simanjuntak, P. N. H. Pokok-Pokok Hukum Perdata Indonesia. Jakarta: Djambatan. 2005.

Soekanto, Soerjono dan Sri Mamudji. Penelitian Hukum Normatif Suatu Tinjauan Singkat. Jakarta: Rajawali Press. 2003.

Soekanto, Soerjono. Faktor-Faktor yang Mempengaruhi Penegakan Hukum. Jakarta: Raja Grafindo Persada. 2007

Soerjono dan H. Abdurahman. Metode Penelitian Hukum. Jakarta: Rineka Cipta. 2003

Subekti. Pokok-Pokok Hukum Perdata. Jakarta: Intermasa. 2003

Supriyadi, Wila Chandrawila. Hukum Perkawinan Indonesia \& Belanda. Bandung: Mandar Maju. 2002

Susilo, Budi. Prosedur Gugatan Cerai. Yogyakarta: Pustaka Yustisia. 2007

Thalib, Sajuti. Hukum Kekeluargaan Indonesia, Berlaku Bagi Umat Islam. Jakarta: Universitas Indonesia Press. 1986

Trianto. Poligami: Perspektif Perikatan Nikah Telaah Konstektual Menurut Hukum Islam Dan Undang-Undang Perkawinan Nomor 1 Tahun 1974.Jakarta: Prestasi Pustaka Publisher. 2007.

Yudisetianto, A, L. Jehani dan Niko Budiman. Panduan Lengkap Mengurus Perijinan dan Dokumen: Pribadi, Keluarga dan Bisnis. Jakarta: Forum Sahabat. 2008 


\section{Perundang-Undangan}

Redaksi Sinar Grafika. KUHAP dan KUHP Dilengkapi dengan Undang-Undang Nomor 27 tahun 1999. Jakarta: Sinar Grafika. 2006

Indonesia. Undang-Undang Nomor 1 Tahun 1974 tentang Perkawinan. Lembar Negara Nomor 1 Tahun 1974. Tambahan Lembar Negara Nomor 3019.

Indonesia. Undang-Undang Nomor 7 Tahun 1989 tentang Peradilan Agama.

Indonesia. Undang-Undang Nomor 48 Tahun 2009 tentang Pokok Kekuasaan Kehakiman

Indonesia. Peraturan Pemerintah Nomor 9 Tahun 1975 tentang Pelaksanaan UndangUndang Nomor 1 Tahun 1974 tentang Perkawinan.

Indonesia. Peraturan Mahkamah Agung Nomor 1 Tahun 2008 tentang Pelaksaaan Mediasi di Pengadilan

\section{Internet}

Hukum Perkawinan. http://akta-online.com/main/index.php

Muhtarom, Ali. Mencari Tolok Ukur Efektivitas Mediasi dalam Perkara Perceraian. http://badilag.net/data/ARTIKEL/tolakukur/efektivitas/mediasi.pdf 